\title{
Short-run Behavior of Defensive Assets in the Ethiopian Commercial Banking Sector
}

\author{
Yitbarek Takele Bayiley ${ }^{1}$
}

\begin{abstract}
The paper aims to identify and measure the impact of factors responsible in shaping the behavior of defensive assets in the Ethiopian banking sector. The focus of the analysis is on the Ethiopian banking sector rather than an individual bank. An attempt is made to capture how the Ethiopian banking sector adjusts its defensive asset position to changes in money supply, relative yields on asset holdings, discount rate, the demand for different bank assets, availability of funds, and legal reserve requirements. Except for required reserves, discount rate and relative yields on asset holdings, the rest of the explanatory variables are statistically significant in explaining the short-run behavior of defensive assets. The paper concludes initial stock of excess reserves, treasury bills, loans and their lag, narrow money supply, saving deposit of the public held with different financial institutions, and bank capital are what explain short-run behavior of defensive assets in the Ethiopian banking sector. Finally, the difference in the behavior of excess \& free reserves found to be negligible which is a signal of insignificant use of short-term borrowings in the Ethiopian commercial banking system.
\end{abstract}

Keywords: Short-run Behavior, Defensive Assets, Commercial Banking Sector, Ethiopia

https://dx.doi.org/10.4314/ejeb.v6i2.3

\footnotetext{
${ }^{1}$ Associate Professor, Department of Management, College of Business and Economics, AAU, E-mail: yitbarekt87@gmail.com
} 


\section{Introduction}

Defensive assets in the banking sector include excess reserves \& free reserves. Free reserves are excess reserves net of borrowings. As the size of defensive assets in a bank asset portfolio affects the profitability, liquidity and safety of banks by influencing the size of earning asset, liquid asset and general reserves, they remain to be topical issue of research in the financial sector. Accordingly, the attempt of this paper is to identify and measure the impact of the major factors that shape the behavior of defensive assets in the Ethiopian banking sector. In this study, rather than using the conventional four variable approach, a broader and new approach is used. Through this study a sincere attempt has been made to understand how the Ethiopian banking sector adjusts its defensive asset position with respect to changes that are internal and external to bank operation. This includes variables such as changes in money supply, relative yields on asset holdings, discount rate, the demand for different bank assets, availability of funds, and legal reserve requirements.

This paper is organized into seven parts. In Part II related literatures are reviewed. Part III lays down the theoretical framework. In part IV the empirical model is set while the required unit root tests that validate the use of the data are discussed in section V. Part VI deals with estimation and results. Finally, the findings of the study are concluded and appropriate policy recommendations are made in part VI of the study.

\section{Empirical Review}

A considerable body of literature exists on matters relating to commercial bank short-run portfolio behavior. Most of the studies are related to borrowing from central banks, adjustments to excess reserves, and earning assets. In their model regarding excess reserves, Bryan and Carleton (1967), Fraser and Rose (1973), and Crammer and Miller (1978) generally used four explanatory variables: the yield on treasury bills, the rate on federal funds, the Federal Reserve discount rate and the difference of treasury bill rate and discount rate. However, if we see the practices in the Ethiopian banking system, there are no applicable interbank borrowing rates and no discount rates are available for use. While the discount rates are nonexistent as no single bank ever used the discount window, there are no adequate data on interbank lending rates as such transactions are sporadic in the Ethiopian banking system and thus determined by banks themselves. Given this, the use of similar variables will not bear any fruit in explaining the behavior of defensive assets in the Ethiopian commercial banking sector. Thus, a broader and alternative approach should be sought. In view of this, Takele (2013) and Takele and Prasad (2012) used antecedent variables that fit into the context of 
the Ethiopian Banking sector though they addressed the treasury bill and excess reserve behaviors than defensive asset behaviors that embrace both excess and free reserves.

An interesting point in relation to this is the bold admission of Fraser and Rose $(1973$; p-4) that their model failed to explain particularly cash assets and excess reserves. Fraser and Rose's (1973) use of total allocable funds as determined by subtracting reserves required against deposits from total assets has problem. This is because the source of bank funds is all liabilities including bank capital: new equities may be issued or earnings may be retained to strengthen a bank's liquidity position. In this paper emphasis is given on studying the behavior of defensive assets in the Ethiopian banking sector in the manner that the above admitted weaknesses in the models of previous authors get alleviated. Rather than using only total allocable funds, other elements of a bank liability portfolio such as retained earnings and new equities issued are incorporated as they have a strong theoretical backing in impacting the behavior of defensive assets. Besides, macro variables such as the supply of both narrow and broad money along with discount rate are used as factors affecting the behavior of defensive assets.

\section{Theoretical Framework}

Both excess reserves and free reserves are defensive assets. Excess reserves include cash in vault, balance with other banks and balances exceeding the required reserve to be held in a central bank while free reserves are excess reserves less borrowings (Frost, 2004). Excess reserves are defined as the amount of legal reserves above or below required reserves (Fraser and Rose, 1973). While the definition by Fraser and Rose (1973) tried to show the existence of both negative and positive defensive position by a bank, Frost (2004) emphasized on the conventional definition of excess reserves where excess reserves are only possibilities of above the required legal reserve position. Given this, it is important to note that the definition by Fraser and Rose (1973) is more comprehensive and profound than Frost's (2004) in that both aspects of excess reserves are covered in the former.

Theoretically, liquidity is required to meet legal requirements, deposit withdrawals and fresh loan requests. Excess liquidity is a defensive position held to meet such legal constraints and unexpected contingencies (Tobin, 1982). Over and above of what has been stated above, the availability of debt instruments and their respective yield rates, the efficiency of the secondary markets and the opportunity cost of holding excess cash are the major factors that determine the size of defensive assets in a bank asset portfolio. 
Borrowings could be sought from central banks, other banks and corporations. Borrowings from corporations could be in the form of certificates of deposits (CDs) of certain denominations and repurchase agreements (repos).However, both of these money market instruments do not exist in the Ethiopian financial system limiting the possible sources of debt instruments traded in the Ethiopian money market to the discount window and the federal funds market. This could be a signal for little or no actual difference between excess reserves and free reserves in the non-earning asset holdings of the Ethiopian commercial banking sector.

Our analyses of the relationship between the different components of asset portfolio and related variables with the defensive asset position of a bank includes treasury bills, yield differential between bank rate and treasury bill rate, loans and investments and the yield differential between them.

The rate on Treasury bills is set as proxy to capture the opportunity cost of holding defensive assets given the nature of Treasury bills as the most liquid earning assets. Bank rate is also set proxy for the cost of negative defensive position (Goldfeld, 1966; and Tobin 1982). Treasury bills, as like other liquid short-term investments, are assumed to have strong negative association with defensive asset holdings. Besides, it is hypothesized that the relationship between bank rate and defensive assets be significant and positive. In their association with Treasury bill rates, defensive assets are expected to maintain a negative relationship. Thus, combining the above two hypotheses, the yield differential between the discount rate and treasury bill rate is expected to show a positive association.

The more a bank invests on earning assets the less will be its defensive assets. Hence, the association between loans and defensive assets shall be a negative one. However, the relationship between lag of loan and excess reserves is not that of disbursement rather collection (loan repayment on installment basis). Thus, a positive association is expected between the two. Finally, a positive association is expected between defensive assets and yield differential of lending and investment in long-term securities.

Regarding, the liability portfolio of a bank, a priori we expect a negative association between required reserves and defensive asset holdings. Given a certain actual reserve position, when required reserves increase, defensive assets should decrease. This is because actual reserve of a bank is the sum total of its required reserve and excess reserve. 
Moreover, a priori defensive assets should maintain positive association both with demand deposits and saving deposits. The more a bank possesses demand deposits than time deposits the more defensive assets it carries, ceteris paribus. This leads us to another hypothesis: a priori defensive assets should maintain positive relationship both with narrow money supply and saving deposit of the public held in all financial institutions. However, the magnitude of relationship with demand deposits should be stronger than saving deposits.

Bank capital which is another element of a bank liability portfolio is expected to maintain a positive relationship with defensive assets though weak. Assuming that a bank raises some capital in the form of additional equity in its attempt to improve its capital adequacy ratio, liquidity position and lending potential, we expect a positive association between bank capital and defensive assets.

\section{Econometric Model}

The asset and liability management of banks involves the management of bank assets, liabilities and factors external to the bank and thus is multivariate. Because bank portfolio elements such as deposits or loans are often related with a time lag to another variable such as investments, the process is dynamic (Cramer and Miller, 1978). With this we can say that the time series financial analysis of bank behavior is both dynamic and multivariate.

Although Aigner (1973), Aigner and Bryan (1971), Anderson and Burger (1969), Bryan (1957), Bryan and Carleton (1967), Fraser and Rose (1973) Hester and Pierce (1975), and Melnik (1975) have dealt with the multivariate aspect of the process, their work lacks the dynamic properties in that the short run behavior are not well addressed. However, the research works of Cramer and Miller (1976 and 1978) though addresses both the multivariate and dynamic properties though the model failed to incorporate important variables such as macroeconomic and asset and liability composition variables whose importance in the study of bank portfolio behavior have already been discussed both in the literature review and theoretical framework parts of this study.

In this model, besides the relevant variables used by previous researchers, size of different asset and liability portfolios and macroeconomic variables are incorporated in an attempt to improve the estimation capacity of previous models.

In an attempt to improve the estimation capacity of the previous models new variables viz., size of different asset and liability portfolios and macroeconomic 
variables are included. This is besides the relevant variables that had been used by previous researchers.

The right-hand side of the general model (see equation 1) constitutes five important components: (1) the lag of the explained variable, (2) asset portfolio variable, (3) liability portfolio variable, (4) yield and interest rate variables, and (5) macro-economic variables. Besides, Dummy variables are included where appropriate. For example, dummies are used in the attempt to capture impact of major policy changes.

In developing this model some very important assumptions are made. These assumptions, though somehow modified, were used by Cramer and Miller (1978).

(1) All the explanatory variables are exogenous - the explanatory variables do not depend on the dependent variable.

(2) There is a time series relationship between the explanatory and explained variable,

(3) the explanatory variable lags or contemporaneous the explained variables, and

(4) the independent variables have no lead or lag relationship

To briefly explain the rationale of setting the assumption that there is a time series relationship between the explanatory and explained variable is the strong belief that the Ethiopian banking system will follow the pattern suggested by most theories of bank financial behavior.

With respect the assumption that the explanatory variables should lag or contemporaneous the explained variable, the rationale for such an assumption to make is for an explanatory variable to cause the explained variable it shall exist before the explained variable (Fisher and et.al, 2007). Finally, regarding the last assumption, for the explanatory variables to claim independent causality, they shall not co-integrate each other. 
The general model that captures the different asset and liability portfolio behavior of commercial banks is presented as follows:

$$
Y_{t}=\alpha_{0}+\alpha_{1} Y_{t-1}+\sum_{i=1}^{n} \alpha_{2} A_{i t}+\sum_{j=1}^{m} \alpha_{3} L_{j t}+\sum_{k=1}^{p} \alpha_{4} R_{k t}+\sum_{l=1}^{q} \alpha_{5} M_{l t}+e_{t}
$$

Where,

$Y_{t}=$ arhount of defensive assets in different periods

$Y_{t-1}=$ the lag of defensive assets

$A_{i}=\mathrm{i}^{\text {th }}$ asset

$L_{j}=j^{\text {th }}$ liability

$R_{k}=$ yield and/or interest rate(s) earned and/or paid on $\mathrm{k}^{\text {th }}$ asset and/or liability, respectively

$M_{l}=\mathrm{I}^{\text {th }}$ macroeconomic variable

$e_{t}=$ stochastic term

Equations in the analysis part of the study are specified as linear in their arguments, and parameters are estimated by least squares methods. Since this is the usual practice (and in the case of time series is normally accompanied by extreme optimism with respect to the behavior of residuals), perhaps no further comment is necessary. On the other hand, the adequacy of the assumption of linearity depends (among other things) upon the absence of interaction among independent variables (Bryan and Carleton, 1967).

The lag of the explained variable shall be included as we are conducting a time series study. The lag variable helps to capture the influence of past portfolio decisions regarding a given explanatory variable on its present behavior. Asset portfolio variables have been included to measure the substitution/complementary effects of other competing/complementing asset portfolio variables and also to measure the relationship between asset and liability portfolios. Liability portfolio elements are also included to measure what sources of funds what uses of funds and how much they cost in their funding. 
Short-run Behavior of Defensive Assets in the Banking Sector

Besides, the inclusion of yield and interest rate variables is intended to measure the impact of yields and interest rates on allocating and attracting funds. Finally, macroeconomic variables are included as they affect deposits size and variability, demand for loans, and securities.

Given the potential relationships explained in the theoretical framework section, the following can be summarized. The lag variable of defensive assets, required reserves, amount of treasury bills in a bank portfolio, loan and its lag, saving deposits, demand deposits, bank capital, Treasury bill rates and discount rates are expected to maintain an association with defensive assets and explain their behavior. Generally, the explanatory variables are entered into the multivariate model according to the theoretical model of bank portfolio behavior as suggested by Crammer and Miller (1978). In view of the general model and theoretical framework, the relationship between defensive assets and the explanatory variables is mathematically represented as shown below.

$\Delta E R=f\left(\Delta E R_{-1}, \Delta R R, \Delta T, \Delta L, \Delta L_{-1}, \Delta M 1, \Delta M 2 M 1, \Delta K, \Delta R D R B, \Delta R L R G\right)$

Eq. 2

$\Delta F R=f\left(\Delta F R_{-1}, \Delta R R, \Delta T, \Delta L, \Delta L_{-1}, \Delta M 1, \Delta M 2 M 1, \Delta K, \Delta R D R B, \Delta R L R G\right)$ Eq. 3

Where,

$\mathrm{ER}(\mathrm{FR})=$ excess (free) reserve of the banking sector,

$\mathrm{ER}_{-1}\left(\mathrm{FR}_{-1}\right)=$ lag of excess (free) reserves

$\mathrm{RR}=$ required reserve,

$\mathrm{T}=$ treasury bills purchased,

$\mathrm{L}=$ loan disbursed,

$L_{-1}=$ loanlag,

$\mathrm{M}_{1}=$ narrow money supply,

$\mathrm{M}_{2} \mathrm{M}_{1}=$ saving deposit held in different financial institutions by the public, i.e.

$\mathrm{M}_{2}-\mathrm{M}_{1}$

$\mathrm{K}=$ bank capital,

$\mathrm{RDRB}=$ yield differential between discount rate and Treasury bill rate, and

RLRG $=$ yield differential between lending and long-term securities

The analytical model developed from the theoretical frameworks that were set in the previous section and the mathematical relationships presented in this section takes the following look.

EJBE Vol. 6 No. 2/2016

Page 191 
$\Delta E R=\alpha_{0}+\alpha_{1} \Delta E R_{-1}+\alpha_{2} \Delta R R+\alpha_{3} \Delta T+\alpha_{4} \Delta L+\alpha_{5} \Delta L_{-1}+\alpha_{6} \Delta M 1+\alpha_{7} \Delta M 2 M 1+\alpha_{8} \Delta K+\alpha_{9} \Delta R D R B+\alpha_{10} \Delta R L R G+e_{t}$

---------Eq. 4

$\Delta F R=\alpha_{0}+\alpha_{1} \Delta F R_{-1}+\alpha_{2} \Delta R R+\alpha_{3} \Delta T+\alpha_{4} \Delta L+\alpha_{5} \Delta L_{-1}+\alpha_{6} \Delta M 1+\alpha_{7} \Delta M 2 M 1+\alpha_{8} \Delta K+\alpha_{9} \Delta R D R B+\alpha_{10} \Delta R L R G+e_{t}$

Eq. 5

Where, $e_{t}$ is a stochastic term

\section{The Data: Nature and Source}

As this research aims at studying the overall portfolio behavior of excess reserves in the Ethiopian commercial banking sector, the banking sector is taken as the research unit. Given this, the best appropriate data type to be considered for such studies are time series data and same has been used. The data used in this study have been collected from quarterly balance sheet and income statement reports submitted by all commercial banks to the National bank of Ethiopia.

The nature of the data used in this study is level data: it is not seasonally adjusted. The study also covers the period from the first quarter of 2000 to the second quarter of 2010. Thus, there are a total of 42 observations included in this study. The study period started from year 2000 as part of the effort to incorporate the impact of private banks in the study as the first private bank of the country after the 1975 nationalization of banks by the military regime was established in 1995 and went operational in 1996. Quarterly data have been used in an attempt to increase the number of observations so that the research could meet econometric tests.

\section{Unit Root Test}

Before the data on excess reserves were used for estimation, they were tested for unit root problem. The test results showed unit root problem with the level data. To correct the unit root problem, the level data were first differenced, and found to be significant at $1 \%$ when checked with Augmented Dickey-Fuller (ADF), and Phillips-Perron (PP) test statistics.

In an attempt to complement the Augmented Dickey-Fuller, and Phillips-Perron test statistics the same decision variables were tested for stationary using Kwiatkowski-Phillips-Schmidt-Shin test statistics and Kwiatkowski-PhillipsSchmidt-Shin (KPSS) test statistics (see table 3). Both of the decision variables 
were not rejected even at $10 \%$ level of significance, which is a very conservative level of significance in KPSS test statistics.

Unit root test is conducted for both excess reserves and free reserves whose short-run behaviors have to be studied. The technique of differencing will be used to seek stationary of the variable to be studied.

With the unit root test, the data on the explained variables is checked for stationarity which is a precondition for studying the short-run behaviors. Both excess reserves and free reserves are found to be stationary in the first differencing.

\section{Estimation and Results}

Based on the above analytical model, the explanatory variables were regressed on the explained variable. All the potential explanatory variables except required reserves and yield differentials are significant. Besides, all the explanatory variables maintained the a priori expected sign. Moreover, the residuals of both of the defensive assets are checked for unit root problem. However, all the three tests: ADF, PP and KPSS indicate the data is stationary (see Table 1).

The graph for the residual of excess reserves indicates that excess reserves were very low in the second and third quarter of year 2000. In this particular period, money supply, loan disbursement and purchase of treasury bills were increasing while withdrawal on earlier loan disbursements was declining. These factors caused the depletion in defensive asset positions of banks. In this period, we can also note that there were no policy changes regarding required reserves. The lag of both of the defensive assets confirm the continued weakening of defensive asset position in the year 2000 .

Table 1: Unit root test of Excess Reserve and Free Reserve Data using Augmented

Dickey-Fuller, Phillips-Perron, and Kwiatkowski-Phillips-Schmidt-ShinTest statistics

\begin{tabular}{|l|l|l|l|l|}
\hline Variable & $\begin{array}{l}\text { First differenced } \\
\text { level data }\end{array}$ & $\begin{array}{l}\text { ADF test statistic } \\
\text { (t-statistics) }\end{array}$ & $\begin{array}{l}\text { PP test statistic } \\
\text { (t-statics) }\end{array}$ & $\begin{array}{l}\text { KPSS test statistic } \\
\text { (LM-Stat) }\end{array}$ \\
\hline Excess reserve & er & $-7.69^{*}$ & $-7.69^{*}$ & 0.07 \\
\hline Free reserve & fr & $-7.68^{*}$ & $-7.68^{*}$ & 0.07 \\
\hline
\end{tabular}

Source: Researcher's own computation of quarterly banking sector data from 2000Q1 to 2010Q2 
* Significant at $1 \%$ for ADF and PP test statistics

${ }^{x}$ The null hypothesis, i.e., the decision variable is stationary could not be rejected even at $10 \%$ level of significance

The other outlier in bank holdings of defensive assets exists in the year 2008. In this particular period, as it can be seen from Figures $1 \& 2$, there is a complete rise in required reserve ratio. The National Bank of Ethiopia has increased the required reserve ratio from $5 \%$ to $10 \%$ in July, 2007. It then again raised the required reserve ratio from $10 \%$ to $15 \%$ in April 2008. This policy change is one of the major factors that affected the extreme decline in excess reserves. Besides, this period also witnessed increase in the purchase of treasury bills, taking it out of its second all-time low after 2004. Money supply declined significantly. The increase in loan disbursements also aggravated the problem while loan repayment was not encouraging. It is the effect of all these major factors that caused the low level of excess reserves in this particular period.

The opposite of what was explained in the above two paragraphs happened in the first quarter of year 2009, where there was strong defensive asset position. The major reason for such position as can be seen in both figures is the low level of loan disbursement. This can be mainly attributed to the credit limit set by the National Bank of Ethiopia on the banking sector besides the rise in the required reserve ratio in the years 2007 and 2008. 


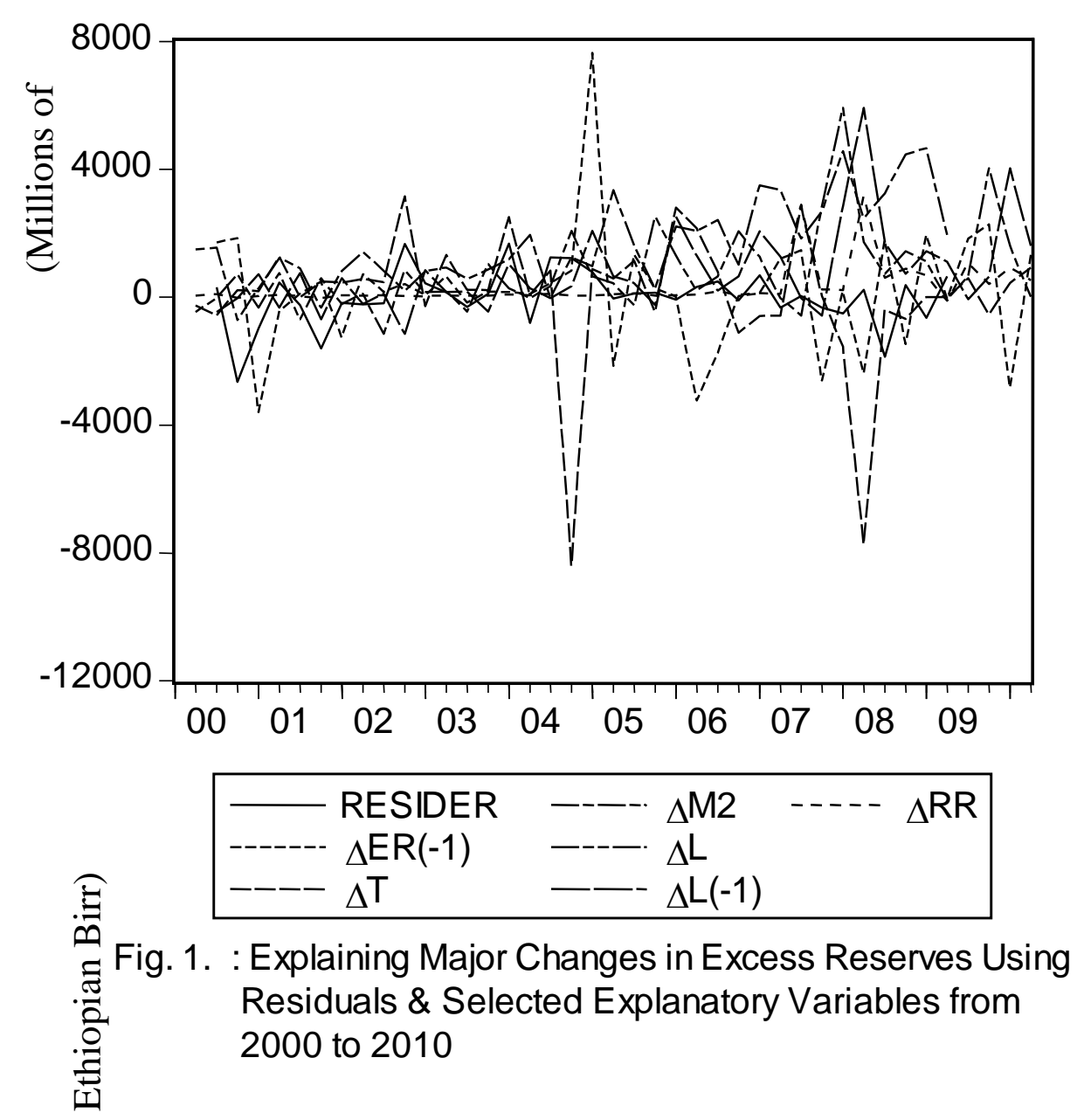

From the above two figures one can learn that there is no difference in the behavior of excess \& free reserves. This is a clear indication that Ethiopian commercial banks use less borrowing in their Asset Liability management. 


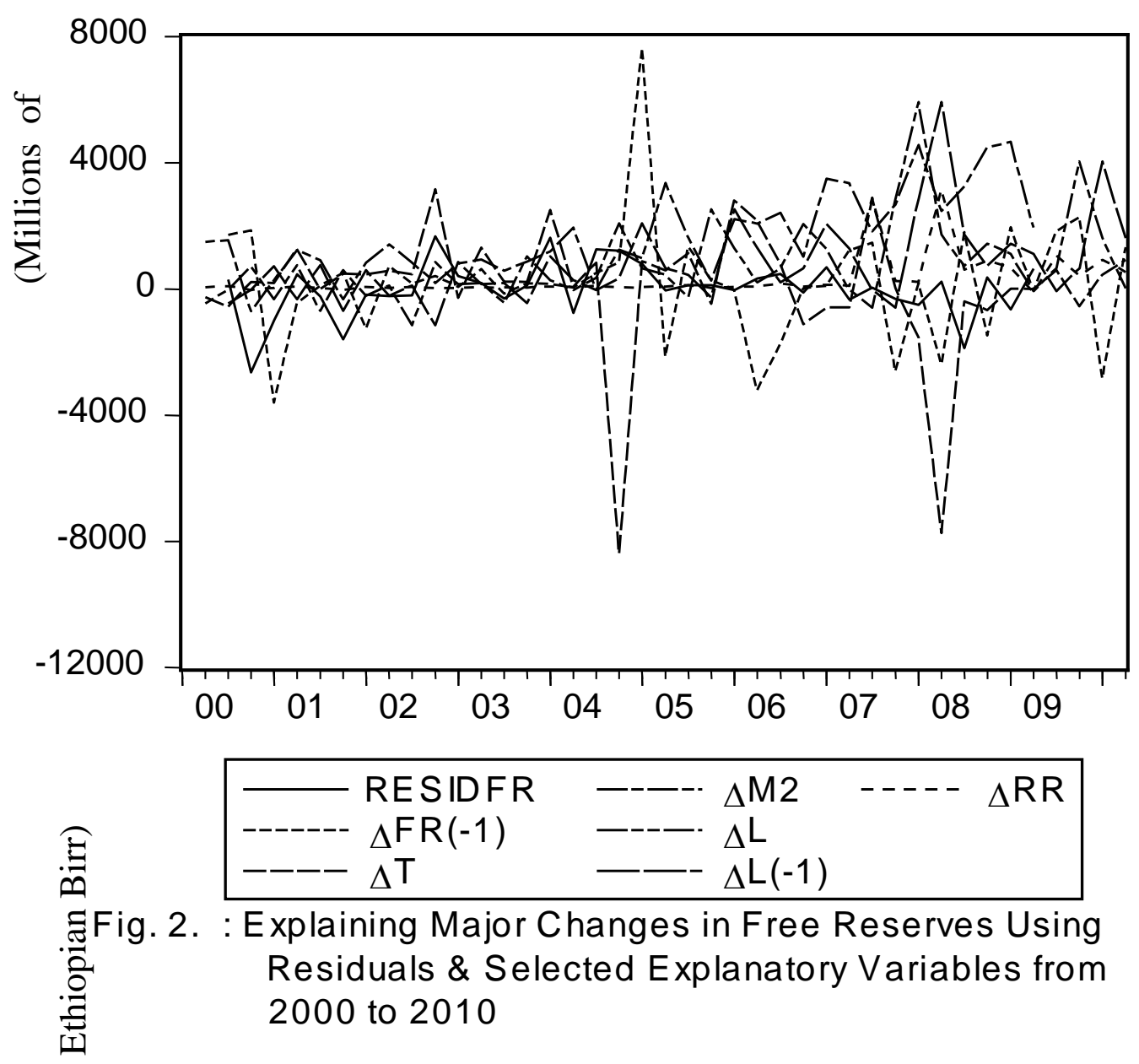

Both excess and free reserves maintained a negative relationship with their respective lags which is an indication of learning from the past and taking corrective actions, accordingly. The lag of a dependent variable indicates the speed of adjustment (Fraser and Rose, 1973; and Goldfeld 1966). From the regression result we can infer that it takes more than fifteen months for commercial banks in Ethiopia to adjust their defensive assets to the desired level. This is in line with Gilbert (1973).

Change in size of treasury bills has shown a negative relationship with both excess \& free reserves. As treasury bills are liquidated, they decrease in size and bring cash into the bank. This improves the defensive asset position of banks. This finding is consistent with Cagan (1969) who found patterns of the free 
reserve ratio of member banks and the commercial paper rate, which behaves similarly to the Treasury bill rate moving in inverse directions. From the regression result we can infer that on the average, every one Ethiopian birr increase of treasury bills decreases defensive assets by 0.84 Ethiopian birr.

The negative association between required reserves and defensive assets given a certain actual reserve position confirmed a priori expectation. However, it is not significant even at $10 \%$. This indicates that the effectiveness of indirect monetary policy transmission mechanisms is weak in the Ethiopian financial system. This result validates the direct intervention of National Bank of Ethiopia in the recent past. Except that the relationship is insignificant, the finding is in agreement with Mattingly and Abou-Zaid (2015)who found interest on excess reserves provide incentives for banks in US and made holding reserves above the required amount implicating negative relationship.

Both loan disbursement and its lag maintained a negative association with defensive assets. While loan disbursement meets a priori expectation, its lag didn't. From this we can infer that when loans are disbursed, the money used for financing the withdrawal of one Ethiopian birr from such loan accounts reduces defensive assets by 0.64 Ethiopian birr. This implies the rest of the one Ethiopian birr, i.e., 0.36 Ethiopian birr during withdrawal gets covered from daily cash inflows such as new deposits. Similarly the rest of the one Ethiopian birr during periods of repayment is used to effect other daily payments such as deposit withdrawals. According to

Khemraj and Proaño (2011) the loan market and the money market are integrated to determine an excess reserves-loan equation.

In the regression result, the coefficient of lag of loans disbursed indicates that only some of the money lent gets withdrawn within the first quarter of its disbursement. From this we can infer that every 1 Ethiopian birr withdrawn after a quarter of fresh loan disbursements reduces defensive assets by 0.74 Ethiopian birr. Similarly, one Ethiopian birr collection made after a quarter of fresh loan disbursement improves defensive assets by 0.74 Ethiopian birr. This implies the rest of the withdrawn money is covered from daily cash inflows such as new deposits. 
Short-run Behavior of Defensive Assets in the Banking Sector

Table 2: Regression of Excess Reserves against its Lag, Treasury Bills, Loans and their lag, Deposits, Required Reserves, Capital, Treasury bill rate and Discount rate

\begin{tabular}{|c|c|c|c|c|}
\hline Variable & Coefficient & Std. Error & t-Statistic & Prob. \\
\hline \multirow[t]{2}{*}{$\mathrm{C}$} & 279.3030 & 342.9829 & 0.814335 & 0.4231 \\
\hline & -0.188184 & 0.106827 & -1.761569 & $0.0904 * * *$ \\
\hline$\Delta R R$ & -0.485184 & 0.322143 & -1.506112 & 0.1446 \\
\hline$\Delta \mathrm{T}$ & -0.844157 & 0.093605 & -9.018317 & $0.0000^{*}$ \\
\hline$\Delta \mathrm{L}$ & -0.638539 & 0.169301 & -3.771616 & $0.0009^{*}$ \\
\hline$\Delta \mathrm{L}=$ & -0.744242 & 0.207045 & -3.594600 & $0.0014^{*}$ \\
\hline$\Delta \mathrm{M}^{-1}$ & 0.408154 & 0.212057 & 1.924735 & $0.0657^{* * *}$ \\
\hline$\Delta \mathrm{M}^{\prime} \mathrm{M}_{\mathrm{s}}$ & 0.800202 & 0.362030 & 2.210320 & $0.0365 * *$ \\
\hline$\Delta \mathrm{K}$ & 0.164115 & 0.086333 & 1.900953 & $0.0689 * * *$ \\
\hline$\triangle \mathrm{RDRB}$ & 210.4110 & 396.1142 & 0.531188 & 0.6000 \\
\hline$\Delta R L R G$ & -234.0707 & 498.0486 & -0.469976 & 0.6424 \\
\hline
\end{tabular}

$R^{2}=0.79$ Adj. $R^{2}=0.70$ S.E $=1039 D W=1.93$

*Denotes significance at $1 \%$ level $* *$ Denotes significance at $5 \%$ level

$* * *$ Denotes significance at $10 \%$ level 
Short-run Behavior of Defensive Assets in the Banking Sector

Table 3: Regression of Free Reserves against its Lag, Treasury Bills, Loans and their lag, Deposits, Required Reserves, Capital, Treasury bill rate and Discount rate

\begin{tabular}{lllll}
\hline \hline Variable & Coefficient & Std. Error & t-Statistic & Prob. \\
\hline \hline $\mathrm{C}$ & $=\overline{277.3280}$ & 341.4475 & 0.812213 & 0.4243 \\
$\Delta \mathrm{FR}(-1)$ & -0.186745 & 0.106339 & -1.756141 & $0.0913^{* * *}$ \\
$\Delta \mathrm{RR}$ & -0.487088 & 0.320705 & -1.518807 & 0.1414 \\
$\Delta \mathrm{T}$ & -0.844714 & 0.093187 & -9.064762 & $0.0000^{*}$ \\
$\Delta \mathrm{L}$ & -0.641720 & 0.168530 & -3.807748 & 0.0008 \\
$\Delta \mathrm{L}(-1)$ & -0.743831 & 0.206122 & -3.608688 & $0.0013^{*}$ \\
$\Delta \mathrm{M} 1$ & 0.412407 & 0.211260 & 1.952134 & $0.0622^{* * *}$ \\
$\Delta \mathrm{M} 2 \mathrm{M} 1$ & 0.801349 & 0.360466 & 2.223094 & $0.0355^{* *}$ \\
$\Delta \mathrm{K}$ & 0.163140 & 0.085855 & 1.900183 & $0.0690^{* * *}$ \\
$\Delta \mathrm{RDRB}$ & 211.6004 & 394.3960 & 0.536518 & 0.5963 \\
$\Delta \mathrm{RLRG}$ & -235.0016 & 495.7418 & -0.474040 & 0.6396 \\
\hline \hline
\end{tabular}

$R^{2}=0.79 \operatorname{Adj} . R^{2}=0.70$ S.E $=1039 \mathrm{DW}=1.93$

*Denotes significance at $1 \%$ level

**Denotes significance at $5 \%$ level $* * *$ Denotes significance at $10 \%$ level

Both excess \& free reserves maintain a positive relationship both with narrow money and saving deposit held in different financial institutions by the public. This has exactly met a priori expectation as demand deposits that are part of narrow money are to be paid on demand and saving deposits with certain preconditions. Such payments will be made using the defensive assets of the bank. Such a relationship indicates that as both demand and saving deposits increase so does defensive assets.

Both narrow money supply and saving deposit held in different financial institutions by the public maintain a positive association with defensive assets which is in conformity with the a priori expectation. The result shows that 
defensive assets of the Ethiopian banking sector increase by 0.41 Ethiopian birr when narrow money increase by one Ethiopian birr. Similarly, excess reserves increase by 0.80 Ethiopian birr when saving deposit held in different financial institutions by the public increases by one Ethiopian birr. This indicates a possible bigger size of saving deposits in the total broad money and a higher variability of saving deposits.

The association between capital and defensive assets turned to be positive, confirming a priori expectation. This indicates when bank capital increases some part of it goes for strengthening the liquidity of the bank. From the result we can infer that on the average, every one Ethiopian birr increase in bank capital increases excess reserves by 0.16 Ethiopian birr.

\section{Conclusion and Policy Implications}

Investment made in treasury bills, amount of loan disbursed and its lag, money supply and changes in capital are what shape the behavior of defensive assets in the Ethiopian commercial banking sector. This is very interesting result in that Ethiopian banks use treasury bills than federal funds markets to adjust treasury bills against the theoretical expectation.

The other conclusion that can be reached using the results of this research is the slow speed of adjustment of defensive asset position by Ethiopian banks indicating inefficiency in the management of bank funds and/or the powerful nature of the exogenous variables (Herrick, 1978). Of course, this has a lot to do with the significant use of the treasury bill market than the federal funds markets by Ethiopian banks which is more cost effective and easily accessible than the former. This emphasizes the need to take policy measures that help banks to easily adjust their defensive asset positions through overhauling the existing policy related to the use of the inter-banking market. Besides, framing a policy that helps the introduction of certificates of deposits, and repos will have paramount importance. The other policy recommendation in relation to improving the speed of adjustment of defensive asset position of banks in Ethiopia is the introduction of a policy initiative that wisely encourages the uses of discount window whenever necessary by outlining both the quantitative and qualitative cost of its use. This will definitely help to improve the speed of adjustment though it encourages the risk-taking behavior of banks. Finally, the overall outcome of the slow speed of adjustment resulted in almost no major difference between excess and free reserve holdings in the Ethiopian commercial banking sector. This, most importantly, is the result of week functioning of federal funds market and other sources of commercial bank borrowings. 
Short-run Behavior of Defensive Assets in the Banking Sector

\section{Reference}

Abdi, Ali. "Towards a Developed and an Efficient Financial Sector in Ethiopia." Economic Focus (2000): 9-22.

Aburime, Uhomoibhitoni. "Determinants of Bank Profitability: Company-Level Evidence From Nigeria." Social Science Research Network 16 March 2008.

Agung, I Gusti Ngurah. TIME SERIES DATA ANALYSIS USING EVIEWS. West Sussex: ohn Wiley \& Sons (Asia) Pvt Ltd, 2009.

Alemu, Lakew. "Financial Sector Reform in EThiopia and the Challenges a Head." Economic Focus (2002): 6-8.

Andhra University, School of Distance Education. Macro Economic Analysis. Visakhapatnem: Sri Ranga Printing Works, 2006.

Asiri. "Assets-liabilities management in banks - a case of Kuwait." Indian Journal of Economics and Business (2007): 103 - 115.

Asli Demirgc-Kunt, Harry Huizinga. "Determinants of commercial bank interest margins and profitability:." 1998.

Asli Demirguc-Kunt, Harry Huizinga. "Financial Structure and Bank Profitability ." 2000.

Athanasoglou, Panayiotis P., Brissimis, Sophocles N. and Delis, Manthos D.

"Bank-Specific, Industry-Specific and Macroeconomic Determinants of Bank Profitability." Journal of International Financial Markets, Institutions and Money (April 2008): 121-136,.

Athanasoglou, Panayiotis P., Delis, Manthos D. and Staikouras, Christos. "Determinants of Bank Profitability in the South Eastern European Region." Journal of Financial Decision Making (2008): 1-17.

Atnafu, Teklewold. "Highlights of Some Considerations in Liberalizing the Financial Sector." Economic Focus (2000): 6-8.

Ayalew, Yohannes. "Sequence of Financial Sector Reform in Ethiopia 1992/93 2000/01 ." Economic Focus (2002): 3-5.

Bain, Peter Howells and Keith. Financial Markets and Institutions. Harlow: Pearson Education, 2007.

Berka, Martin. "Multiclollinearity." 2007.

Borja Amor-Tapia, Maria T. Tascón, José L. Fanjul. "Determinants of Commercial Banks' Residual Profitability: An Industry Approach ." Spanish Journal of Finance and Accounting (2008 ): 469-500.

Börner, Jan-Christoph. A bio-economic model of small-scale farmers' land use decisions. Hamburg: Institut für Landwirtschaftliche Betriebslehre, 2006.

Bryan, Dennis J. Aigner and William R. "A Model of Short-Run Bank Behavior." The Quarterly Journal of Economics (1971): 97-118. 
Short-run Behavior of Defensive Assets in the Banking Sector

—. "A Model of Short-Run Bank Behavior." The Quarterly Journal of Economics (Feb., 1971): pp. 97-118.

Bryan, William R. "Bank Adjustments to Monetary Policy: Alternative Estimates of the Lag." The American Economic Review (Sep., 1967): pp. 855-864.

Cagan, P. (1969). Interest rates and bank reserves-A reinterpretation of the statistical association. In Essays on Interest Rates, Volume 1 (pp. 223271). NBER.

Carleton, William R. Bryan and Willard T. "Short-Run Adjustments of an Individual Bank." Econometrica (Apr., 1967): pp. 321-347.

David A. Dickey, William R. Bell, Robert B. Miller. "Unit Roots in Time Series Models: Tests and Implications." The American Statistician (Feb., 1986): pp. 12-26.

Dendir, Seife. "Prudential Performance of the Ethiopian Banking Sector (1991/92 - 1997/98)." Economic Focus (2000): 27 - 31.

Dennis Cox, and Michael Cox. The Mathematics of Banking and Finance. West Sussex: John nWiley \& Sons Ltd. , 2006.

DERMINE, B ISSADA. Asset \& Liability Managemnt: A Guide to Value Creation and Risk Control. London: Pearson Education Limited, 2002.

Dietrich, Andreas and Wanzenried, Gabrielle. "Determinants of Bank Profitability Before and During the Crisis: Evidence from Switzerland." SSRN (2010).

Dietrich, Andreas Wanzenried and Gabrielle. "Determinants of Bank Profitability Before and During the Crisis: Evidence from Switzerland." Social Science Research Network 14 January 2010.

Donald D.Hester, John F.Zoellner. "The Relation between Bank Portfolios and Earnings: An Econometric Analysis." Review of Economics and Statistics 1966.

Fielitz, Loeffler. "A Linear Programming Model for Commercial Bank Liquidity Management." Financial Management (1979): 41-50.

Fisher, Colin. RESEARCHING AND WRITING A DISSERTATION: A Guide for Business Students. Hawlow: Pearson Education, 2007.

Frederi W.Bell, Neil B.Murphy. "Economies of Scale in Commercial Banking." New England Business Review 1967.

Frederik S. Mishkin, and Stabley G. Eakins. Financial Markets and Institutions. Boston: Pearson Addison Wesley, 2006.

Friedman, Thomas L. Understanding Globalization: The Lexus and The Olive Tree. New York: Anchor Books, 2000.

Frost. The Bank Analyst's Handbook: Money, risk and conjuring tricks . John Wiley \& Sons Ltd, (2004). 
Short-run Behavior of Defensive Assets in the Banking Sector

Frost, Stephen M. The Bank Analyst's Handbook . West Sussex: John Wiley \& Sons, Ltd, 2004.

Gdey, Belay. Axumite Coins, Currency and Banking in Ethiopia September. Addis Ababa: Commercial Printing Press, 1987.

Geda, Alemayehu. "The Structure and Performance of Ethiopia's Financial

Sector in the Pre- and Post-Reform Period with a Special Focus on Banking." World Institute for Development Research Paper October 2006.

Geda, Tony Addison and Alemayehu. "Ethiopia's New Financial Sector and Its New Regulation." Discussion Paper No. 2001/55. Helsinki: World Institute for Development Economics Research (WIDER) of the United Nations University, August 2001.

George J. Benston, Clifford W. Smith, Jr. "A Transactions Cost Approach to the Theory of Financial Intermediation." The Journal of Finance (28-30): 215-231.

Gilbert, R. A. (1973). The effects of lagged reserve requirements on the reserve adjustment pressure on banks. Financial Analysts Journal, 34-43.

Girma, Abu. "Financial Sector Liberalization in Developing Countries." Economic Focus (2000): 23 - 26.

GIUDICI, PAOLO. Applied Data Mining:Statistical Methods for Business and Industry. West Sussex: John Wiley \& Sons Ltd, 2003.

Goldfeld, Srephen M. Commercial Bank Behavior and Economic Activity. Amsterdam: North - Holand Publishing Company, 1966.

Goldfeld, Stephen M. Commercial Bank Behavior and Economic Activity. Amsterdam: Nprth_holland Publishing Company, 1966.

Hammer, Kalman J. Cohen and Frederick S. Analytical Methods in Banking. Homewood: Richard D. Irwin, Inc, 1966.

Haslem, John A. "A Statistical Analysis of the Relative Profitability of Commercial Banks." The Journal of Finance (1968): 167-176.

Herrick, Tracy G. Bank Analyst's Handbook. New York: John Wiley and Sons, 1978.

—. Bank Analyst's Handbook. New York: Jhon Wiley \& Sons, 1978.

Hester, Donald D. and Pierce, James L. Bank Management and Portfolio Behavior. New Haven: Yale University Press, 1975.

Hester, Donald D. Indian banks Their Portfolios, Profits, and Policy. Bombay: Bombay University Press, 1963.

Hulett. "A Short-run Model of Commercial Bank Portfolio Behavior." Journal of Finance (1967): 478-489.

Hulett, David T. " A Short-Run Model of Commercial Bank Portfolio Behavior." The Journal of Finance (Sep., 1967): pp. 488-489. 
Short-run Behavior of Defensive Assets in the Banking Sector

IMF. "The Federal Democratic Republic of Ethiopia Selected Issues and Statistical Appendix." IMF Country Report January 2005.

—. "The Federal Democratic Republic of Ethiopia: 2007 Article IV

Consultation-Staff Report; Staff Supplement; Public Information Notice on the Executive Board Discussion; and Statement by the Executive Director for the Federal Democratic Republic of Et." 2006.

—. The Federal Democratic Republic of Ethiopia: 2007 Article IV Consultation-Staff Report; Staff Supplement; Public Information Notice on the Executive Board Discussion; and Statement by the Executive Director for the Federal Democratic Republic of Ethiopia. Washington, D.C.: International Monetary Fund, 2007.

—. The Federal Democratic Republic of Ethiopia: 2007 Article IV Consultation-Staff Report; Staff Supplement; Public Information Notice on the Executive Board Discussion; and Statement by the Executive Director for the Federal Democratic Republic of Ethiopia. Washington, D.C.: IMF Publication Services, 2007.

—. The Federal Democratic Republic of Ethiopia: 2007 Article IV Consultation-Staff Report; Staff Supplement; Public Information Notice on the Executive Board Discussion; and Statement by the Executive Director for the Federal Democratic Republic of Ethiopia. Washington, D.C: International Monetary Fund, 2006.

James P.Furniss, Paul S.Nadler. "Should Banks Re-price Corporate Services?" harvard Business review May-June 1966.

JESÚS HUERTA DE SOTO, TRANSLATED BY MELINDA A. STROUP. Money, Bank Credit, and Economic Cycles. Ludwig von Mises Institute, ,2002 (2009).

John Adams, Hafiz T.A. Khan, Robert Raeside, and David White. Research Methods for Graduate Business and Social Science Students. Los Angeles: Response Books, SAGE, 2007.

Joseph, Tabi ATEMNKENG J. and NZONGANG. "Market Structure and Profitability Performance in the Banking Industry of CFA Countries: The Case Of Commercial Banks In Cameroon." Journal of Sustainable Development in Africa (2006).

Khemraj, T., \&Proaño, C. R. (2011). Excess bank reserves and monetary policy with a lower-bound lending rate.Working Paper 04/2011, Department of Economics, New School for Social Research.

Koop, Gary. ANALYSIS OF ECONOMIC DATA. West Sussex: John Wiley \& Sons, Ltd, 2005.

Kozo Kiyota, Barbara Peitsch and Robert M. Stern. "The Case for Financial Sector Liberalization in Ethiopia." 17 August 2007.

EJBE Vol. 6 No. 2/2016 
Short-run Behavior of Defensive Assets in the Banking Sector

Kwast, Mayron L. and John T. Rose. "“Pricing, Operating Efficiency and." Journal of Banking and Finance (1982): 233-254.

Kyriaki Kosmidou, Constantin Zopounidis. Goal Programming Techniques for Bank Asset Liability Management. http://www.infibeam.com/Books/springer-publisher/, 2004.

L.Silber, William. Portfoliio Behavior of Financial Institutions; An Emperical Study with Implications for Monetary Policy, Interst-Rate Determination, and Financial Modeling. Holt, Rinehart and Winston, inc. , 1969.

Leonall C. Andersen, Albert E. Burger. "Asset Management and Commercial Bank Portfolio Behavior: Theory and Practice." Papers and Publications of the Twenty - Seventh Annual Meeting of the American Finance Association. Chicago, Illinois: Blackwell Publishing for the American Finance Association, 1969. 206-221.

Leonard, Giri Kumar. Tayi and Paul A. "Bank Balance-Sheet Management: An Alternative Multi-Objective Model." The Journal of the Operational Research Society (Apr., 1988): pp. 401-410.

—. "Bank Balance-Sheet Management: An Alternative Multi-Objective Model." The Journal of the Operational Research Society (1988): 401- 410.

Loukoianova, Elena. "Analysis of the Efficiency and Profitability of the Japanese Banking System." 2008.

Machiraju, H.R. Modern Commercial Banking, Second Edition. New Age International (P) Ltd., Publishers, 2008.

Machiraju, H.R. Modern Commercial Banking. New Delhi: New Age International, 2008.

Matthews, Thompson. The Econopmics of Banking. West Sussex: John Wiley \& Sons Ltd, 2005.

Mattingly, M., \&Abou-Zaid, A. S. (2015). The High Levels of Excess Reserves 2008-2012: An Investigation into the Determinants of the US Banks' Liquidity Hoarding during the Global Financial Crisis.

Mauri, Arnaldo. "Origins and Early Development of Banking in EThiopia." UNIMI Economics Working Paper No. 04.2003 March 2003.

—. "The Ethiopian Banking System." G. Dell'Amore, ed., Cariplo - Finafrica (1971): 61-70.

—. "The Ethiopian Banking System. BANKING SYSTEMS IN AFRICA G. Dell'Amore, ed., Cariplo - Finafrica." SSRN (1971): 61-70.

Melnik. "Commercial-Bank Portfolio Behavior: An Empirical Analysis." The Journal of Finance (1969).

Melnik, Arie. "Short Run Determinants of Commercial Bank Investment Portfolios: An Empirical Analysis." The Journal of Finance (Jun., 1970): pp. 639-649. 
Short-run Behavior of Defensive Assets in the Banking Sector

Miller, Robert H. Cramer and Robert B. "Dynamic Modeling of Multivariate Time Series for Use in Bank Analysis." Journal of Money, Credit and Banking (Feb., 1976): pp. 85-96.

—. "Multivariate Time Series Analysis of Bank Financial Behavior." The Journal of Financial and Quantitative Analysis ((Dec., 1978): pp.10031017.

Mishkin, Frederic S. The Economics of Money, Banking, and Financial Markets. Boston: Pearson Addison Wesley, 2004.

- . The Economics of Money, Banking, and Financial Markets. New York: Pearson Addison Wesley, 2004.

NBE. "Frequently asked questions (FAQ) about the activities of the Bank." Biritu (2010): 38.

Ofcansky, Berry. Ethiopia, a country study. Kessinger Publishing, LLC, 1991.

Olaf Hiibler, and Joachim Frohn. Modern Econometric Analysis: Surveys on Recent Developments. Berlin: Springer, 2006.

Panayiotis P. Athanasoglou, et.al. "BANK-SPECIFIC, INDUSTRY-SPECIFIC AND MACROECONOMIC DETERMINANTS OF BANK PROFITABILITY." Bank of Greece Working Paper No.25 June 2005. Panayiotis P. Athanasoglou, Manthos D. Delis and Christos Staikouras.

"Determinants of Bank Profitability in the South Eastern European Region." Journal of Financial Decision Making (2006): 1-17.

Pearce, W.O. "Functional Cost Analysis: A tool of Bank management." Federal Reserve Bank of Richmond Monthly Review November 1967.

PETER HOWELLS, and KEITH BAIN. Financial Markets and Institutions. Harlow: Prentice Hall, 2007.

Peter Howells, and Keith Bain. The Economics of Money, Banking and Finance. London: Prentice Hall, 2005.

Porter, Richard C. A Model of Bank Portfolio Behavior. New Haven: Cowles Foundation for Research in Economics, January, 1960.

Robinson, Ronald I. The management of Bank Funds. New York: McGraw - Hill Book Company, Inc, 1951.

Rose, Donald R. Fraser and Peter S. "Short-Run Bank Portfolio Behavior: An Examination of Selected Liquid Assets." The Journal of Finance (May, 1973): pp. 531-537.

Rose, Fraser and. "Short-Run Bank Portfolio Behavior: An Examination of Selected Liquid Assets." American Finance Association (1973). Roussakis, Emmanuel N. Commercial Banking in an Era of Deregulation,. Westport: Praeger, 1997. 
Short-run Behavior of Defensive Assets in the Banking Sector

Samy Ben Naceur, Mohamed Goaied. "The Determinants of Commercial Bank Interest Margin and Profitability: Evidence from Tunisia." Frontiers in Finance and Economics (2008): 106-130.

Silber, William L. PORTFOLIO BEHAVIOR OF FINANCIAL

INSTITUTIONS: An Empirical Study with Implications for Monetray

Policy, Interest-Rate Determination, and Financial Modeling. New York:

Holt, Rinehart and Winston, Inc, 1969.

Somashekar, N.T. Banking. New Age International (P) Ltd., 2009.

Soto, Jesus Huerta De. Money, Bank Vredit, and Economic Cycles. Alabama:

Ludwing von Mises Institute, 2009.

Stein, Jeremy C. "An Adverse-Selection Model of Bank Asset and Liability Management with Implications for the Transmission of Monetary Policy." The RAND Journal of Economics (1998): 466-486.

Stephen M. Miller, Athanasios G. Noulas. "Portfolio mix and large-bank profitability in the USA." Applied economics (1997): 505-512.

Tabi ATEMNKENG J., NZONGANG Joseph. "Market Structure and Profitability Performance in the Banking Industry of CFA Countries: The Case Of Commercial Banks In Cameroon." Journal of Sustainable Development in Africa (2006).

Takele, Yitbarek. "A DYNAMIC AND MULTIVARIATE ANALYSIS OF TREASURY BILL BEHAVIOR IN A BANK ASSET PORTFOLIO." European Scientific Journal 9.7 (2013): 275-273.

Tarhan, Paul A. Spindt and Vefa. "Liquidity Structure Adjustment Behavior of Large Money Center Banks." Journal of Money, Credit and Banking (May, 1980): pp. 198-208.

Thompson, Kent Matthews and John. The Economics of Banking. West Sussex: John Wiley \& Sons, Ltd, 2005.

Tobin, James. "The Commercial Banking Firm: A Simple Model." Scand. J. Of Economics (1982): 495-530.

Tony Addison, Alemayehu Geda. "Ethiopia's New Financial Sector." 2001.

Toroyan, George C. Anayiotos and Hovhannes. "Institutional Factors and Financial SectorDevelopment: Evidence from Sub-Saharan Africa." IMF Working Paper 2009.

Tsay, George C. Tiao and Ruey S. "Model Specification in Multivariate Time Series." Journal of the Royal Statistical Society. Series B (Methodological) (1989): pp. 157-213.

Vefa Tarhan, Paul A. Spindt. "Bank earning asset behavior and causality between reserves and money : Lagged versus contemporaneous reserve accounting." Journal of Monetary Economics (1983): 331-341 . 
Short-run Behavior of Defensive Assets in the Banking Sector

Vogelvang, Ben. Economet cs: Theory and Applications with EViews. Harlow: Prentice Hall, 2005.

Yitbarek Takele, Siva Prasad. "SHORT-RUN BEHAVIOR OF EXCESS RESERVES A CASE STUDY ON ETHIOPIAN COMMERCIAL BANKING SECTOR." Asian Journal of Research in Banking and Finance 2.4 (2012): 48-59.

Ziemba, M. I. Kusy and W. T. "A Bank Asset and Liability Management Model." Operations Research (May - Jun., 1986): pp. 356-376. 